\title{
EFFECTS OF HUMIC ACID AND BREAD YEAST ON GROWTH AND YIELD OF LETTUCE (LACTUCA SATIVA L.) UNDER PROTECTED CONDITIONS.
}

\author{
IBRAHIM RAJAB IBRAHIM \\ Dept. Protected cultivation, technical institute of zakho, Duhok polytechnic university, \\ Kurdistan Region-Iraq.
}

(Received: August 4, 2020; Accepted for Publication: October 25, 2020)

\begin{abstract}
A research study was conducted in a plastic house $\left(500 \mathrm{~m}^{2}\right)$ at the vegetable research field of the protected cultivated department at Zakho Technical Institute, Dohuk Polytechnic University, Kurdistan Region-Iraq. The period of study was at Autumn season of 2018 to investigate the effect of foliar application of humic acid in three levels $(0,2$ and 4$) \mathrm{ml} / \mathrm{L}$ and bread yeast with three levels $(0,2.5$ and 5$)$ $\mathrm{g} / \mathrm{L}$ on the growth and yield of lettuce (Cv. Romaine). The results showed that treatment with foliar spraying of humic acid and yeast had significant effects on growth and yield of letteus, The level (4) $\mathrm{ml} / \mathrm{L}$ , also the foliar spraying of yeast at the level (5) $\mathrm{g} / \mathrm{L}$ had the highest results in the growth of vegetative characters ( No. of leaves. plant ${ }^{-1}$ 76.41leaves and chlorophyll content\% $45.04 \%$ ), leaf mineral content (Nitrogen, Potassium and Phosphorus) and head weight (gm) of lettuce when encountered with control and other treatments.
\end{abstract}

\section{INTRODUCTION}

$\mathbf{L}$ ettuce (Lactuca sativa L.) is one of the crops used among the salad crops. Lettuce is possessing an excellent nutritional value with high contents of vitamins and other various minerals. In general, the lettuce is eaten fresh as a green salad.

Foliar application of biostimulants such as humic acid and yeast is beneficial and has resulted in significant stimulation of growth as well as increased in the quantity and quality of a vast number of crop species. It causes a profound enhance in nutrient uptake by plants and considers as a source of nutrients as well as regulators substances necessary for plants growth and development (El-Nemr et al., 2012; Karakurt et al., 2009; Yildirim \& Yapici, 2007). Yeast is well-known to possess valuable nutritional and growth motivation properties due to its content of natural growth regulators (hormones), sugars, carbohydrates, and amino acids (Abbas, 2013). Humic acid, on the other hand, constitutes (65-70\%) of soil organic matter and has a hormone-like action which enhanced the plant growth and increased uptake of nutrient besides improved plant tolerance to abiotic stress conditions (El-Hefny, 2010).

Several researches and studies showed that the humic acid and yeast improved vegetative growth significantly and yield in different crops. Haidar Al-madhagi (2019) illustrated that foliar spray of humic acid and yeast enhanced the production of greenhouse cucumber (cucumis sativus L.). The treatment with bread yeast and humic acid on the growth and yield traits of broad bean (Vicia Faba L.) was studied by Samira et al. (2019) and showed that use of combined humic acid and bread yeast caused improvement in vegetative growth and characters of the crop as compared to untreated plants.

\section{MATERIALS AND METHODS}

The field trial encompassed the foliar application of three levels of humic acid $(0,2$, and 4) $\mathrm{ml} / \mathrm{L}$ and three levels of yeast $(0,2.5$ and 5) $\mathrm{g} / \mathrm{L}$ on the lettuce (cv. Romaine) under greenhouse conditions. The seeds of lettuce were sown on $17^{\text {th }}$ October, 2018 and the transplants were cultivated in the plastic house on $4^{\text {th }}$ November, 2018. The first spray of humic acid was carried out on $5^{\text {th }}$ December, 2018. The second spray was done on $15^{\text {th }}$ December, 2018 and the third spray was on $25^{\text {th }}$ December, 2018. The trial treatments were organized in a Randomized Complete Block Design (RCBD) with three replicates. The data analysis was done using SAS program. The leaf samples were 
taken from full-physiologically grown leaves. All samples were let to dry at room temperature then were put in hot air oven at $(70) \mathrm{C}^{0}$ for two days. The oven-dried samples were grounded by electric grinder then $0.5 \mathrm{gm}$ of each sample was digested using perchloric acid and concentrated sulphuric acid. The following parameters were measured:-

\subsection{VEGETATIVE GROWTH PARAMETERS}

\section{1- Number of Leaves per plants ${ }^{-1}$}

At the end of the growing season, the number of leaves per plant was accounted from five plants within inner rows from each experimental unit and the average was estimated.

\section{2- Chlorophyll Content (\%)}

In leaves, The chlorophyll content was calculated for fully grown leaves of five plants from each experimental unit in the inner rows through the use of (Chlorophyll Meter, SPAD502, Konica Minolta) and the average was accounted.

\section{3- Nitrogen Concentration (\%)}

The total percentage of nitrogen in lettuce leaf was calculated depending on the Kjeldahl modified method using the Microkjeldahl apparatus (A.O.A.C., 1980) that sited by Black (1965).

\section{4- Phosphorus Concentration (\%)}

The phosphorus content in leaves was measured depending on colorimetric methods by using the Spectrophotometer (Matt, 1970).

\section{5- Potassium Concentration (\%)}

The total percentage of potassium was evaluated depending on the flame method by use of the Flame photometer instrument (A.O.A.C., 1970 and Al-Sahaf, 1989).

\subsection{YIELD GROWTH PARAMETERS Head Weight (gm)}

The weighing of the head weight of lettuce was performed using the electric balance at any harvest from five plants in the experimental unit and the average was calculated.

\section{RESULTS}

\subsection{Vegetative Growth Parameters 1- Number of Leaves. Plants-1}

Table (1) illustrated the foliar spraying of Humic Acid and bread yeast and their interactions caused a significant increase in the number of leaves per plant. The maximum number of leaves (86.63) was recorded for a plant that received humic acid with level (4) $\mathrm{ml} / \mathrm{L}$ and the yeast at level (5) $\mathrm{g} / \mathrm{L}$ as compared with control and other treatments. The lowest number of leaves (55.97) was accounted for control plants. In the case of the mean value for HA and yeast application, a significant difference has also been found and the highest mean values (76.41 and 76.28) were measured for HA and yeast respectively.

Table 1: Effect of of HA and bread yeast and their interaction on the number of leaves plants ${ }^{1}$ of lettuce.

\begin{tabular}{ccccc}
\hline Yeast g/L & \multicolumn{3}{c}{ Humic Acid mI/L } & Yeast g/L \\
\cline { 2 - 4 } & 0 & 2 & 4 \\
\hline 0 & $55.97 \mathrm{~d}$ & $63.63 \mathrm{~cd}$ & $57.50 \mathrm{~cd}$ & $59.03 \mathrm{~b}$ \\
\hline 2.5 & $69.00 \mathrm{~b}-\mathrm{d}$ & $74.75 \mathrm{abc}$ & $85.10 \mathrm{ab}$ & $76.28 \mathrm{a}$ \\
\hline 5 & $70.92 \mathrm{a}-\mathrm{d}$ & $67.47 \mathrm{~cd}$ & $86.63 \mathrm{a}$ & $75.01 \mathrm{a}$ \\
\hline Humic Acid $\mathrm{ml} / \mathrm{L}$ & $65.29 \mathrm{~b}$ & $68.62 \mathrm{ab}$ & $76.41 \mathrm{a}$ &
\end{tabular}

Means within column row and their interactions followed with the same letters are not significantly different from each other according to Duncan's multiple range test at $0.05 \%$ level.

\section{2-Chlorophyll Content (\%)}

The content of leaves chlorophyll for lettuce was affected due to the application of humic acid and yeast as illustrated in table (2). Both biostimulants significantly ameliorated the percent of chlorophyll. The peak percentage of chlorophyll (48.33) \% was estimated in the leaves of lettuce plants treated with (4) $\mathrm{ml} / \mathrm{L}$ of humic acid and (5) g/L of yeast when compared to control and the rest treatments. The minimum value of chlorophyll (39.11) \% was found in leaves of plants applied with HA at (2) $\mathrm{ml} / \mathrm{L}$ and yeast at (2.5) g/L. Concerning the mean values, no significant differences were observed between treatment for yeast application whereas the same was not true for HA application and the greatest mean value of chlorophyll percentage 
(45.04) \% was determined for $\mathrm{HA}$ at the level (4) $\mathrm{ml} / \mathrm{L}$
Table 2: Effect of HA and bread yeast and their interaction in the total chlorophyll content on lettuce

leaves.

\begin{tabular}{ccccc}
\hline \multirow{2}{*}{ Yeast $\mathbf{~ g / L}$} & \multicolumn{3}{c}{ Humic Acid $\mathbf{~ m l} / \mathbf{L}$} & \multirow{2}{*}{ Yeast g/L } \\
\cline { 2 - 4 } & 0 & 2 & 4 & \\
\hline 0 & $41.86 \mathrm{bc}$ & $43.83 \mathrm{abc}$ & $40.31 \mathrm{c}$ & $42.00 \mathrm{a}$ \\
\hline 2.5 & $42.72 \mathrm{bc}$ & $39.11 \mathrm{c}$ & $46.46 \mathrm{ab}$ & $42.76 \mathrm{a}$ \\
\hline 5 & $41.53 \mathrm{bc}$ & $42.71 \mathrm{bc}$ & $48.33 \mathrm{a}$ & $44.19 \mathrm{a}$ \\
\hline Humic Acid ml/L & $42.04 \mathrm{~b}$ & $41.88 \mathrm{~b}$ & $45.04 \mathrm{a}$ &
\end{tabular}

Means within column row and their interactions followed with the same letters are not significantly different from each other according to Duncan's multiple range test at $0.05 \%$ level.

\subsection{YIELD GROWTH PARAMETERS Head Weight}

According to the results in table (3), the foliar application of HA and yeast and their interaction led to a statistical improvement in the head weight of lettuce crop. The dual interaction between humic acid and yeast at (4) $\mathrm{ml} / \mathrm{L}$ of $\mathrm{HA}$ and (5) $\mathrm{g} / \mathrm{L}$ of yeast produced the highest head weight (981.33) gm in comparison with the control that owned the lowest head weight (586.50) gm. Regarding the mean values for HA and yeast application, there were significant differences in the head weight of lettuce and the maximum mean head weights (839.50) gm and (827.36) gm were measured for yeast and HA application

respectively

Table( 3):- Effect of of HA and bread yeast and their interaction in the head weight gm of lettuce.

\begin{tabular}{ccccc}
\hline Yeast g/L & \multicolumn{3}{c}{ Humic Acid ml/L } & Yeast g/L \\
\cline { 2 - 4 } & 0 & 2 & 4 & \\
\hline 0 & $586.50 \mathrm{~d}$ & $808.83 \mathrm{abc}$ & $632.50 \mathrm{~cd}$ & $675.94 \mathrm{~b}$ \\
\hline 2.5 & $747.50 \mathrm{bcd}$ & $797.33 \mathrm{a}-\mathrm{c}$ & $868.25 \mathrm{ab}$ & $804.36 \mathrm{a}$ \\
\hline 5 & $774.33 \mathrm{a}-\mathrm{c}$ & $762.83 \mathrm{bcd}$ & $981.33 \mathrm{a}$ & $839.50 \mathrm{a}$ \\
\hline Humic Acid $\mathrm{ml} / \mathrm{L}$ & $702.78 \mathrm{~b}$ & $789.67 \mathrm{ab}$ & $827.36 \mathrm{a}$ & \\
\hline
\end{tabular}

Means within column row and their interactions followed with the same letters are not significantly different from each other according to Duncan's multiple range test at $0.05 \%$ level.

\section{Nitrogen Concentration ( $\%$ )}

The obtained results showed that both the HA and yeast along with their interactions resulted in a prominent increment in the leaf content of nitrogen as shown in table (4). The biggest percentage of nitrogen (1.75) \% was estimated in the leaves of lettuce plants that given humic acid with the level (4) $\mathrm{ml} / \mathrm{L}$ and yeast with the level (5) $\mathrm{g} / \mathrm{L}$ comparing with control and the remaining treatments. On the other hand, the least percentage of nitrogen was recorded in the leaves of control plants which was $(0.72) \%$. Significant variations were also noticed in the nitrogen percentage of leaves in term of mean value for HA and yeast application. The biggest the mean value of nitrogen percentage (1.52) \% was measured for HA application and the highest mean value of nitrogen (1.34) \% was recorded for yeast application 
Table( 4):- Effect of HA and bread yeast and their interactions in the nitrogen percentage of lettuce leaves.

\begin{tabular}{ccccc}
\hline Yeast g/L & \multicolumn{3}{c}{ Humic Acid ml/L } & Yeast g/L \\
\cline { 2 - 5 } & 0 & 2 & 4 & $0.98 \mathrm{~b}$ \\
\hline 0 & $0.72 \mathrm{c}$ & $0.91 \mathrm{bc}$ & $1.32 \mathrm{ab}$ & $1.26 \mathrm{ab}$ \\
\hline 2.5 & $1.00 \mathrm{bc}$ & $1.30 \mathrm{abc}$ & $1.48 \mathrm{ab}$ & $1.34 \mathrm{a}$ \\
\hline 5 & $0.98 \mathrm{bc}$ & $1.30 \mathrm{abc}$ & $1.75 \mathrm{a}$ & \\
\hline Humic Acid ml/L & $0.90 \mathrm{~b}$ & $1.17 \mathrm{~b}$ & $1.52 \mathrm{a}$ & \\
\hline
\end{tabular}

Means within column row and their interactions followed with the same letters are not significantly different from each other according to Duncan's multiple range test at $0.05 \%$ level.

\section{Phosphorus Concentration (\%)}

The phosphorus content of lettuce leaves was significantly improved with foliar spraying of humic acid. The supreme content of phosphorus $(0.84) \%$ was estimated in the interaction between (4) $\mathrm{ml} / \mathrm{L}$ of humic acid and the level (5) $\mathrm{g} / \mathrm{L}$ of yeast, the minimum percentage of phosphorus element $(0.15) \%$ was determined with the interaction between humic acid at (2) $\mathrm{ml} / \mathrm{L}$ and the yeast at $(5) \mathrm{g} / \mathrm{L}$. for the mean value effect, no significant differences were appeared in mean phosphorus percentage for yeast application whereas the vice versa was observed for HA application, and the maximum mean value for phosphorus content (0.42) \% was measured for HA application as clarified in the table (5).

Table( 5):- Effect of HA and bread yeast and their interactions in the phosphorus percentage of lettuce leaves.

\begin{tabular}{ccccc}
\hline Yeast g/L & \multicolumn{3}{c}{ Humic Acid mI/L } & Yeast $\mathbf{g} / \mathbf{L}$ \\
\cline { 2 - 4 } & 0 & 2 & 4 & $0.20 \mathrm{a}$ \\
\hline 0 & $0.19 \mathrm{~b}$ & $0.19 \mathrm{~b}$ & $0.22 \mathrm{~b}$ & $0.20 \mathrm{a}$ \\
\hline 2.5 & $0.19 \mathrm{~b}$ & $0.21 \mathrm{~b}$ & $0.19 \mathrm{~b}$ & $0.39 \mathrm{a}$ \\
\hline Humic Acid $\mathrm{ml} / \mathrm{L}$ & $0.17 \mathrm{~b}$ & $0.15 \mathrm{~b}$ & $0.84 \mathrm{a}$ &
\end{tabular}

Means within column row and their interactions followed with the same letters are not significantly different from each other according to Duncan's multiple range test at 5\% level.

\section{Potassium Concentration (\%)}

The data showed in the table (6) the highest potassium percentage (21.00) \% was determined due to the interaction of humic acid with the level (4) $\mathrm{ml} / \mathrm{L}$ and yeast with the level (5) g/L while the lowest value of potassium content (13.67) \% was estimated for plants treated with (4) $\mathrm{ml} / \mathrm{L}$ of $\mathrm{HA}$ and $(0) \mathrm{g} / \mathrm{L}$ of yeast and plants that received HA with $(0) \mathrm{ml} / \mathrm{L}$ and yeast with (2.5) $\mathrm{g} / \mathrm{L}$. in case of mean value effect, no significant effect was observed for HA application while the mean value for yeast application possessed a significant influence on the potassium percentage of lettuce leaves. The premium mean value of potassium content (17.89) \% was obtained for yeast application

Table 5: Effect of HA and bread yeast and their interactions in the potassium percentage of lettuce

leaves.

Table( 6):- Effect of HA and bread yeast and their interactions in the potassium percentage of lettuce leaves.

\begin{tabular}{|c|c|c|c|c|}
\hline \multirow[t]{2}{*}{ Yeast $\mathrm{g} / \mathrm{L}$} & \multicolumn{3}{|c|}{ Humic Acid ml/L } & \multirow[t]{2}{*}{ Yeast $\mathrm{g} / \mathrm{L}$} \\
\hline & 0 & 2 & 4 & \\
\hline 0 & $18.00 \mathrm{ab}$ & $14.00 \mathrm{~b}$ & $13.67 b$ & $15.22 b$ \\
\hline 2.5 & $13.67 \mathrm{~b}$ & $16.67 \mathrm{ab}$ & $17.33 \mathrm{ab}$ & $15.89 \mathrm{ab}$ \\
\hline 5 & $15.33 \mathrm{~b}$ & $17.33 \mathrm{ab}$ & $21.00 \mathrm{a}$ & $17.89 \mathrm{a}$ \\
\hline Humic Acid ml/L & $15.67 \mathrm{a}$ & $16.00 \mathrm{a}$ & $17.33 \mathrm{a}$ & \\
\hline
\end{tabular}

Means within column row and their interactions followed with the same letters are not significantly different from each other according to Duncan's multiple range test at $0.05 \%$ level. 


\section{DISCUSSION}

the evidence from the previous results that spraying humic acid and the bread yeast to the foliage of lettuce crop had a significant impact on the vegetative growth, head weight, and mineral content of leaves in comparison with untreated plants (control). The dual interaction between both bio-stimulants at the dose (4) $\mathrm{ml} / \mathrm{L}$ of HA and (5) $\mathrm{g} / \mathrm{L}$ of yeast positively enhanced vegetative growth parameters, head weight as well as mineral content. The increase in the leaf number per plant may be due to the yeast capability to supply the stimulants (Gibberellins, Cytokinins, and Auxins) for plant growth particularly which their function is to ameliorate the growth of plant cell and its division (Bowen and Rovira, 1991, Ahmed et al 1995, Glick, 1995 and Sarhan 2008).

The enhancement in vegetative growth could be due to the major role of humic acid in promoting photosynthesis and respiration in plants as well as enhancing permeability of the cell membrane. The improve in the mineral content of lettuce may refer to the ability of humic acid and bread yeast to increase the uptake of nutrients from the soil and their action as sources of mineral plant nutrients as well as regulators of the release of nutrients (Atiyeh $e t$ al., 2002; Chen et al., 1990; El-Nemret et al., 2012).

Moreover, the foliar treatment of humic acid and the bread yeast positively affect the head weight of lettuce crop. The increase in the yield of lettuce may be attributed to the positive effect of hormone-like substances especially gibberellins and mineral nutrients that stimulate the the nutrient uptake and productivity and as consequence plant growth (El-Hefny, 2010). Mirdad (2016) showed that the application of humic acid on Crisphead lettuce enhanced the production of the crop. The ameliorated head weight may also be because of the role of the bread yeast and its content of hormones and vitamin B5 and minerals which effectively motivate direction and metabolites translocation from leaves in to the productive organs. The yeast has a prominent role in the synthesis of protein, and nucleic acid (Natio et al,1981).

\section{REFERENCES}

Abbas, S.M. (2013). The influence of biostimulants on the growth and on the biochemical composition of Vicia faba cv. Giza 3 beans. Romanian Biotechnological Letters 18(2), 8061-8068.

Adenine on RNA and protein synthesis in intact bean leaves at various

Ahmed, F.F., M.M.A.Ragab. A.A. Gobara and A.E.M. Mansour (1995). The eneficial of supplying active dry yeast to some nutrients foliage spraying for Anna apple trees Malus domestica Symposium on Foliar fertilization a Technique to Improve Productivity and Decrease pollution. Cairo. Egypt.

Atiyeh, R.M., Lee, S., Edwards, C.A., Arancon, N.Q., \& Metzger, J.D. (2002). The influence of humic acids derived from earthwormprocessed organic wastes on plant growth. Bioresource Technology, 84(1), 7-14. https://doi.org/10.1016/S0960-8524(02)000172 .

Bowen, G. D. and A. D. Rovira. (1991). The rhizosphere, the hidden half of the hidden half. P. 641-669. In:y. Waisel; A. Eshel; and V. Kalkaf; (cds). Plant Roots, the Hidden Half Marcel Dekker New York. Camb. 104: 99106.

Chen, Y., Aviad, T., MacCarthy, P., Clapp, C. E., Malcolm, R. L.,\& Bloom, P. R. (1990).Humic Substances in Soil and Crop Sciences: Selected Readings. DOI: 10.2136/1990.humicsubstances.frontmatter.

El-Hefny, E. M. (2010). Effect of saline irrigation water and humic acid application on growth and productivity of two cultivars of Cowpea (Vigna unguiculata L. Walp). Aust. J. Basic Appl. Sci., 4: 6154-6168.

El-Nemr, M.A., El-Desuki, M., El-Bassiony, A.M., \& Fawzy, Z.F. (2012). Response of growth and yield of cucumber plants (Cucumis Sativus L.) to different foliar applications of humic 
acid and bio-Stimulators. Australian Journal of Basic and Applied Sciences, 6(3), 630-637.

Glick, B.R. (1995). The enhancement of plant growth by free living bacteria. Cand. J. Microbiology. 41:109-117.

Isam Abdulbaset Haidar Al-madhagi (2019). Effect of humic acid and yeast on the yield of greenhouse cucumber (cucumis sativus L.). journal of horticulture and postharvest research, vol. 2(1), 67-82.

Karakurt, Y., Unlu, H., Unlu, H., \& Padem, H. (2009). The influence of foliar and soil fertilization of humic acid on yield and quality of pepper. Acta Agriculturae Scandinavica, Section B - Soil and Plant Science, 59(3), 233237. DOI: 10.1080/09064710802022952.

Mirdad, Z.M. (2016). Effect of $\mathrm{N}$ fertigation rates and humic acid on the productivity of crisphead lettuce (Lactuca sativa L.) grown in sandy soil. Journal of Agricultural Science (Toronto), 8(8), 149-157. DOI:10.5539/jas. v8n8p149
Natio , K.; S. Nagama ; K. Furye and H. Suzuki (1981). Effect of benzyl

Samira Hassan Yousif, Kurdistan Hassan Yousif and Sana Mohammad Salih (2019). Effect of bread yeast and humic acid on yield traits of broad beans (Vicia Faba L.). Journal of University of Duhok., Vol. 22, No.1 (Agri. and Vet. Sciences), Pp 98-106.

Sarhan, T.Z. (2008). Effect of biological fertilizers, Animed residues, and Urea on Growth and yield of potato plant C.V. Desiree Solanum tuberosum L. Ph. D. Thesis Horticulture Sciences and Landscape Design (Vegetable), University of Mosul, College of Agriculture and Forestry.

stages of agein. Plant Physiol., 52: 342-348.

Yildirim, I., \& Yapici, B.M. (2007). Inhibition of conidia germination and mycelial growth of Botrytis cinerea by some alternative chemicals. Pakistan Journal of Biological Sciences, 10(8), 1294-1300. DOI: 10.3923/pjbs.2007.1294.1300 